IMPACT OF EMPIRE (ROMAN EMPIRE, 27 B.C. - A.D. 406) 1 


\title{
ADMINISTRATION, PROSOPOGRAPHY AND APPOINTMENT POLICIES IN THE ROMAN EMPIRE
}

PROCEEDINGS OF THE FIRST WORKSHOP OF THE INTERNATIONAL NETWORK

IMPACT OF EMPIRE

(ROMAN EMPIRE, 27 B.C. - A.D. 406)

LEIDEN, JUNE 28 - JULY 1, 2000

\author{
EDITED BY \\ LUKAS DE BLOIS
}

J.C. GIEBEN, PUBLIS HER

AMSTERDAM 2001 
The workshop was funded by the Netherlands Organisation for Scientific Research (NWO), the Royal Netherlands Academy of Arts and Sciences (KNAW), The Research School of Classics in The Netherlands (OIKOS), and the Faculty of Law of the University of Leiden.

We owe thanks to Jasper Oorthuys, the assistant editor of this volume.

No part of this book may be translated or reproduced in any form, by print, photoprint, microfilm, or any other means, without written permission from the publisher

(C) 2001 by J.C. Gieben

ISBN 9050632483

Printed in The Netherlands 
ADMINISTRATION, PROSOPOGRAPHY AND APPOINTMENT POLICIES IN THE ROMAN EMPIRE

First workshop of the international network Impact of Empire June 28 - July 1, 2000, in the "Gravensteen", at the Faculty of Law, University of Leiden, The Netherlands.

\section{CONTENTS \\ - Introduction \\ $\mathrm{V}$ \\ - Abbreviations \\ VIII}

\section{$\underline{\text { Part } 1}$}

- W. Eck, Spezialisierung in der staatlichen Administration des Römischen Reiches in der Hohen Kaiserzeit

1

- S. Demougin, Considérations sur l' avancement dans les carrières procuratoriennes équestres

24

- O.J. Hekster, All in the Family: The Appointment of Emperors Designate in the Second Century A.D.

35

- M.A. Speidel, Specialisation and Promotion in the Roman Imperial Army 50

- I.P. Haynes, The Impact of Auxiliary Recruitment on Provincial Societies from Augustus to Caracalla

62

- R. Haensch, Milites legionis im Umfeld ihrer Provinz. Zur Rekrutierungspraxis, sozialen Position und zur 'Romanisierung' der Soldaten der niedergermanischen Legionen im 2. und 3. Jahrhundert 84

\section{Part 2}

- M. Peachin, Jurists and the Law in the Early Roman Empire 109 
- A.J.B. Sirks, Making a Request to the Emperor: Rescripts in the Roman Empire

121

- L. de Blois, Roman Jurists and the Crisis of the Third Century A.D. in the Roman Empire

136

- W.J. Zwalve, In re Iulius Agrippa's Estate. Some Observations on Q.

Cervidius Scaevola, Iulia Domna and the Estate of Iulius Agrippa

154

- B.H. Stolte, The Impact of Roman Law in Egypt and the Near East in the Third Century A.D.: The Documentary Evidence. Some Considerations in the Margin of the Euphrates Papyri (P. Euphr.)

167

- U. Manthe, Das Fortleben des Gaius im Oströmischen Reich

180

\section{$\underline{\text { Part } 3}$}

- G.P. Burton, The Imperial State and its Impact on the Role and Status of Local Magistrates and Councillors in the Provinces of the Empire 202

- J.F. Gardner, Making Citizens: The Operation of the Lex Irnitana 215

- A. Krieckhaus, Roma communis nostra patria est? Zum Einfluss des römischen Staates auf die Beziehungen zwischen Senatoren und Ihren Heimatstädten in der Hohen Kaiserzeit 230

- J.S. Richardson, Social Mobility in the Hispanic Provinces in the Republican Period

246

- A. Caballos, Der Aufstieg lokaler Eliten Spaniens in die Reichselite 255 